\title{
Accounting for PPP Pension Projects
}

\author{
Xinyi Tu \\ School of Economics and Management, Nanjing University of Science and Technology, Nanjing \\ 210094, China; \\ tuxinyi2017@163.com
}

Keywords: PPP Project; Public-private Partnership Pojects; Pension; Accounting

\begin{abstract}
In recent years, with the strong support of the state, more and more projects have begun to operate in a government and social capital cooperation. These projects are called PPP. Along with the aging population in China, the social support coefficient has risen, and the old-age care business has a long way to go. A sound and effective PPP pension model has guiding significance for the construction of China's old-age care, and is conducive to more harmonious society.
\end{abstract}

\section{Introduction}

As early as 1994, the PPP project was in the pilot phase, and in recent years it has become more widely available. On August 26, 2015, the State Council executive meeting hosted by Premier Li Keqiang specifically pointed out that it is necessary to "accelerate the construction of major projects such as shed reform, railway and water conservancy, set up PPP project guidance funds, and expand effective investment demand”. In recent years, the central government has encouraged social capital to enter the public service sector and encourage the development of the PPP model. The imbalance between the demand and supply of the pension industry in China has also promoted the development of the PPP model in the pension industry.

The PPP model refers to the relationship between the government and the private organization, in order to provide certain public goods and services, based on the concession agreement, to sign the contract to clarify the rights and obligations of both parties, so that allowing the partners to achieve more favorable outcomes than expected individual actions.

\section{PPP Pension Project}

\subsection{Analysis of the Necessity of PPP Pension Project}

With the change of China's population structure, the imbalance between supply and demand of the old-age industry is becoming more and more serious, the scale of the old-age market is expanding, social capital is gradually participating in the old-age service, and the PPP pension model is being implemented at the same time. Facing the family pension from prosperity to decline and the reality of community pension is not yet popular, the supplementary role of institutional pension is particularly important. In February 2018, the Ministry of Finance announced the fourth batch of government and social capital cooperation demonstration projects. The total investment is 
4.5 billion yuan, of which 8 pension projects. According to the data of the PPP Center of the Ministry of Finance, there are currently 286 PPP pension projects in the library, including 42 national demonstration projects. The PPP model has become an important way to develop the aged care service industry.

Introducing the PPP model into the construction of institutional pension services has the following three benefits. First, it is conducive to achieving the combination of fiscal and social capital to reduce the financial burden. The financing function included in the PPP model can expand the source of funds for the construction of pension institutions. On the one hand, the full effect of fiscal funds can be fully exerted. On the other hand, the addition of social capital can make up for the existing funding gap and reduce the financial burden. Second, it is conducive to integrating the advantages of the government, the market and the society to improve the quality of old-age services. This kind of social capital tends to be profit-seeking, and this profit-seeking will mobilize more business wisdom to meet the needs of market pension, and the government can play its functional role of industry supervision. In this way, the utility of complementary advantages is achieved. Third, it is conducive to diversifying risks and achieving economies of scale. The risk of the initial investment in the old-age service industry and the long payback period makes the private institutions less dynamic. The PPP model's risk-reward sharing characteristics allow the public sector and non-public sector cooperation to maximize the efficiency of risk allocation.

\subsection{Feasibility analysis of PPP pension project}

According to the content of Figure 1 below, the characteristics of the PPP model applicable project and the characteristics of the pension project are analyzed and compared. It can be found that although the pension industry itself has defects in some aspects, it is in line with the characteristics of PPP mode applicable projects in most respects. Coupled with the government's high degree of emphasis and support, the pension program is basically suitable for the PPP model.

Figure 1 Comparison of PPP model and pension project

\begin{tabular}{|l|l|l|}
\hline $\begin{array}{l}\text { Characteristics of projects suitable for } \\
\text { PPP mode }\end{array}$ & $\begin{array}{l}\text { Is it } \\
\text { suitable? }\end{array}$ & Characteristics of pension projects \\
\hline Large investment scale & Yes & $\begin{array}{l}\text { Large investment in the early stage, long } \\
\text { operating cycle, mostly 20 30 years }\end{array}$ \\
\hline Long-term stable demand & Yes & $\begin{array}{l}\text { In an aging society in the future, market } \\
\text { demand will remain stable for a long time. }\end{array}$ \\
\hline Flexible price adjustment mechanism & No & $\begin{array}{l}\text { Due to the different types of services and } \\
\text { service levels the fee-based pricing } \\
\text { mechanism is complicated, and the price } \\
\text { adjustment method is difficult to define. }\end{array}$ \\
\hline Higher degree of marketization & No & $\begin{array}{l}\text { The degree of marketization is not high, } \\
\text { most of them are government public } \\
\text { utilities, and more and more economic } \\
\text { entities are gradually participating. }\end{array}$ \\
\hline $\begin{array}{l}\text { Infrastructure and public service } \\
\text { projects }\end{array}$ & Yes & \begin{tabular}{l} 
Infrastructure and public service projects \\
\hline
\end{tabular}
\end{tabular}

\subsection{The Situation Analysis of PPP pension projects}

The number of national PPP pension projects is relatively low. As of June 30, 2016, there were 239 national pension PPP projects, accounting for $2.57 \%$ of the total number of 9265 PPP projects 
nationwide. Compared with the PPP mode, there are more municipal engineering (3241), transportation (1132), and district development (554), the number of pension projects is smaller. Compared with the same project in the public service field, such as education (483) and medical care (433), the proportion of pension projects is relatively small, too. At the same time, the total investment of the national pension projects was 141.1 billion yuan, accounting for $1.33 \%$ of the total investment of the national PPP projects of 10.6 trillion yuan, and the amount of money is also very small.

In addition, the national PPP pension project is unevenly distributed. Shandong and Guizhou provinces use the PPP model for the most pension projects. However, there are also 8 provinces or municipalities directly under the central government have no pension projects under the PPP model (including Shanghai) in the current project library. The PPP pension program is mainly invested in the old-age care industry, elderly apartments and medical and nursing projects.

\section{Accounting treatment of PPP pension projects}

At present, more than 83\% of China's pension PPP projects use BOT (Build-Operate-Transfer) or BOO (Build-Own-Operate) operations, with a single type, and there is no innovation in the way of operation in the pension sector. In addition to BOT and BOO, there are a few projects that use TOT (Transfer-Operate-Transfer),ROT(Reconstruction-Operation-Transfer),O\&M(Entrusted Operations), and MC (Management Contract). Now, take the BOT method as an example to analyze the accounting treatment of the PPP pension project from the perspective of the project company.

\subsection{The stage of Construction}

During the construction period, the project company shall confirm the relevant income and expenses in accordance with the "Accounting Standards for Business Enterprises No. 15 Construction Contract” for the construction services provided. The income from the construction contract shall be measured at the fair value of the consideration received or receivable, and the financial assets or intangible assets shall be recognized under specified circumstances.

1) Cost incurred during construction.

Dr: Construction-in-process - Contract cost

Cr: Raw materials、Accrued wages、Cash in bank, etc.

2) Confirm relevant income and costs during construction.

Dr: Operating costs、Construction-in-process_—Contract gross profit

Cr: Prime operating revenue

3) The confirmation of the construction contract has the following three conditions.

First, within a certain period after the contract stipulates that the infrastructure is completed, the project company may unconditionally receive a certain amount of monetary funds or other financial assets from the contract awarding party; Or in the case that the project company provides the operating service charge below a certain limit amount. Or if the project company's provision of operating services is less than a certain amount of money, the contract awarding party is responsible for the compensation of the relevant difference to the project company in accordance with the contract. Under these circumstances, financial assets should be recognized at the same time as the revenue is recognized, and processed in accordance with the "Accounting Standards for Business Enterprises No. 22 - Recognition and Measurement of Financial Instruments”. The accounting entries should be listed as follows:

Dr: Cash in bank、 Account receivable

Cr: Project settlement 
Secondly, the contract stipulates that the project company has the right to charge the object of obtaining the service within a certain period of time after the completion of the relevant infrastructure. However, if the amount of the fee is uncertain, the right does not constitute an unconditional right to receive cash. Under these circumstances, intangible assets should be recognized while recognizing revenue. If the interest on the loan occurs during the construction process, it shall be handled in accordance with the provisions of the "Accounting Standards for Business Enterprises No. 17 - Borrowing Costs". The accounting entries should be listed as follows:

Dr: Intangible assets

Cr: Project settlement

4) Carry forward construction costs.

Dr: Project settlement

Cr: Construction-in-process - C Contract cost 、 Construction-in-process_—Contract gross profit

\subsection{The stage of Operation}

After the infrastructure is completed, the project company shall confirm the income related to the follow-up business services in accordance with the "Accounting Standards for Business Enterprises No. 14 - Revenue”.

1) Confirmation of income during the operation phase.

The business related to pensions is recognized as the main business income, and other businesses are recognized as other business income. The accounting entries should be listed as follows:

Dr: Cash in bank、 Tax and associate charge

Cr: Prime operating revenue、Other operating revenue、Tax payable

2) Confirmation of expenses during the operation phase.

The expenses incurred by the pension project business are recognized as the main business cost, and others are recognized as other business costs. The accounting entries should be listed as follows:

Dr: Prime operating costs、Other operating costs

Cr: Cash in bank、Accrued wages

\subsection{The stage of Handover}

During the transition phase, the investor did not recognize the project and its ancillary facilities as fixed assets. The relevant concession has been amortized as intangible assets during the concession period, and routine maintenance has ensured that the project and its ancillary facilities are in good technical condition. In the state, there is no need to make special accounting for the handover.

\section{Suggestions for PPP pension projects}

\subsection{Suggestions for the internal project}

First of all, in the accounting of assets, PPP projects should pay attention to distinguishing two subjects, one is the government main body and one is a PPP project company. After the project company completes the construction of the old-age care institution, the assets owned by the project company other than the franchise agreement can be recognized as fixed assets, but the assets agreed 
in the specific agreement should not be recognized as fixed assets, but financial Assets or intangible assets.

Second, in the PPP model project, the government may also provide certain capital support to the project company. Therefore, the accounting of the payments made by the government should also be noted.

If the funds paid by the government are within the scope of the license agreement or related to the services of a particular project, the accounting entries should be listed as follows before the construction of the project:

Dr: Cash in bank

Cr: Deposit received

At the time of construction, accounting entries should be listed as follows:

Dr: Cash in bank

Cr: Long-term receivables

If the cash paid by the government is outside the scope of the franchise agreement, the payment will be made before the construction of the project. The accounting entries are:

Dr: Cash in bank

Cr: Deferred income

During the construction of the project, the accounting entries are:

Dr: Deferred income

Cr: Non-operating income

The payment is made when the project is completed, and the accounting entries are:

Dr: Cash in bank

Cr: Non-operating income

\subsection{Suggestions for external projects}

Although China's PPP model has been produced for a long time, its application time is not long, and its construction and operation experience is more obtained from abroad. China's laws and regulations on PPP are extremely lacking. The special effect of the law is a solid backing to ensure the interests of all parties, and can effectively ensure that the public sector and private enterprises play their special role within the allowable scope. Moreover, the current policy documents that guide the application of the PPP model to China's old-age care institutions are low in legal effectiveness, and most of them are some guidance. It is difficult to clarify the responsibilities of the government and the private sector in the process of cooperation, and it is difficult to protect the rights of both parties. The part is even more relevant legal advice can be verified, which must be resolved for the smooth implementation of PPP pension projects.

As mentioned before, because the service type and service level are different, the charging pricing mechanism is complicated, and the price adjustment method is difficult to define. Therefore, it is imperative to establish a standard pricing system. The pricing system must be open and transparent. On the one hand, it must be acceptable to most ordinary people, and it cannot be set too high. On the other hand, because of the involvement of the private sector, it must be guaranteed to have a certain profitability, so that investors can get better returns. The government can grant subsidies when appropriate.

Third, it does not rule out the existence of fraudulent relationship between the private sector and the government sector. Therefore, it is necessary to ensure the healthy development of the pension institutions under the PPP model, which is essential for the effective supervision of PPP pension projects. For this, a third-party evaluation agency can be introduced to conduct performance evaluation of all-inclusive indicators for the services of the aged care institutions. This is used to 
urge all PPP pension projects to be continuously improved and continuously optimized to better serve the people.

\section{Conclusions}

Today, as the problem of aging is deepening, China's basic national conditions and the actual problems of the existing old-age care institutions' supply gaps, as well as the publicity of old-age service facilities, The PPP model has been widely used in China's infrastructure construction and welfare institutions to make a significant contribution to China's old-age care, and it is an operational development model that is in the interest of all parties.

In recent years, all parties in the society have given great attention to this. There are various project models in the accounting of PPP pension projects. This paper only focuses on the accounting under the BOT model, so for some less-used model accounting needs to be continuously improved. Based on the existing model, we will continue to innovate and develop, and find out the development mode that truly meets the actual needs. More importantly, the external environment optimization of the PPP pension model needs to continue, and the government's policy and supervision in this area need to be improved. I hope that the more shallow suggestions in this paper can have certain reference value.

\section{References}

[1] Reijniers J J A M. Organization of public-private partnership projects: The timely prevention of pitfalls [J]. International Journal of Project Management, 1994, 12(3): 137-142.

[2] Tang L Y, Shen Q, Cheng E W L. A review of studies on public-private partnership projects in the construction industry [J]. International Journal of Project Management, 2010, 28(7): 683-694.

[3] Yuan J, Zeng A Y, Skibniewski M J, et al. Selection of performance objectives and key performance indicators in public-private partnership projects to achieve value for money [J]. Construction Management and Economics, 2009, 27(3): 253-270.

[4] Hwang B G, Zhao X, Gay M J S. Public private partnership projects in Singapore: Factors, critical risks and preferred risk allocation from the perspective of contractors [J]. International Journal of Project Management, 2013, 31(3): 424-433.

[5] Grimsey D, Lewis M K. evaluating the risks of public private partnerships for infrastructure projects [J]. International journal of project management, 2002, 20(2): 107-118.

[6] Davis E P. Pension funds: retirement-income security and capital markets: an international perspective [J]. OUP Catalogue, 1998.

[7] Hodge G A, Greve C. Public-private partnerships: an international performance review [J]. Public administration review, 2007, 67(3): 545-558.

[8] Public-private partnerships: managing risks and opportunities [M]. John Wiley \& Sons, 2008. 